\title{
HORTATORY AND ANALYTICAL EXPOSITION ANALYSIS ON STUDENT'S WRITING
}

(Case Study of 2nd Semester University of Serang Raya Students)

\author{
Ratu Dea Mada Badriyah, Eva Fachriyah, Arifiatul Hasanah \\ University of Serang Raya \\ Serang, Indonesia \\ ratudea@unsera.ac.id, Fachriyaheva@gmail.com, arifiasolehah@gmail.com
}

\begin{abstract}
This research aims to identify how students at second semester in University of Serang Raya can differentiate between hortatory and Analytical Expositions. The method used is descriptive study. The sample of this research are 7 classes of second semester in University of Serang Raya. The tool for data collecting was a written text that students wrote in two kinds of text, Hortatory and Analytical Exposition in a side by side form ( 2 columns) and a quiz in a google forms. It is hope that by analysing the students' writing, they are able to comprehend and differentiate the structure and the content of Hortatory and Analytical Exposition
\end{abstract}

Keyword: writing, hortatory exposition, analytical exposition, reiteration, recommendation.

\section{INTRODUCTION}

There are four basic language skills in English such as listening, speaking, reading and writing. Those are important skills in learning English. From those skills, "writing is considered as the most difficult skill for L2 learners to master" (Richards and Renandya, 2002: 303). Based on that statement, the difficulty in writing is not only on how to generate and organize the ideas, but also how to translate the ideas into the readable text. Relating to the difficulty of writing above, the students should pay more attention in writing and on how to express the ideas, thoughts, and opinions in the written form.

Moreover, as it is stated in the previous paragraph, writing is one of the important skills in English. There are some reasons relating to the importance of writing skill for students. The first is to lead the students to the academic success in the school. By developing the writing skill, students will gain benefit in writing their paper or essay assignments from a single paragraph and building multi-paragraphs essay.

Then, the other reason for students is to develop their critical thinking so that they will have confidence in writing academic papers. By having good critical thinking in writing skill, they will be confident to put the ideas into the paper and write their papers easily in several pages long. 
The ability to write effectively becomes important in our global community. Technology upgrading allows nations and cultures throughout the world to interact with each other, communication across languages become ever more essential. The ability to write is becoming widely recognized as an important skill for educational, business and personal reasons. Therefore, the purpose of teaching language should be as a system of communication rather than as an object of study.

Writing skill is very difficult for many students. Richards and\& Renandya (2002, p. 30) Richards and Renandya (2002, p. 30) state that there is no doubt that writing skill is difficult to be mastered by second language learners. The difficulty is not only found in generating and organizing ideas, but also in translating ideas into readable text. In line with them, Hartfiel also states that the difficulty of writing is because it entails several components to be considered by the learner, such as contents, rhetoric, vocabularies, grammatical structures, and writing mechanics like punctuation and capitalization (1985, p. 102).Itwas statedthat in Educational Unit Curriculum (KTSP) of senior high school at grade eleven in writing, students are expected to express the meaning of a short functional text and essay in the form of
Report, Narrative, Analytical exposition, Hortatory exposition, and Spoof.

Dealing with English writing activity in the classroom, there is one genre among student which is closely related to it. It is called Exposition. According to Pardiyono (2007), in exposition genre, there are two kinds of communicative purposes: analytical exposition and hortatory exposition. He further adds that analytical exposition gives viewpoint/ ideas about certain topic which needs more attention, clarification, and explanation of something without trying to persuade the reader to have pro or contra toward the case. While hortatory exposition is kind of exposition that is called persuasive which persuades the readers that something should or should not be the case.

According to Byrne in Roza (2011), there are five components that should be considered in writing:

1. Organizing idea

Ideas are the most important factors in writing, because nobody can write meaningfully, if he/she has not anything in mind yet.

\section{Grammar}

The grammar of language is a description of way that the language behaves. Without having knowledge of grammar the writer cannot make his/her language communicative to 
a great variety of reader from different situation.

3. Vocabulary

Vocabulary is important in writing because by having many vocabularies, a writer can make readers explore more deeply in what he/she is telling about.

4. Mechanics

- Punctuation

Punctuation plays as an important role in helping reader to establish intonation. In other word, punctuation is standard set of marks used in written and printed texts to clarify meaning and to separate sentences, words, and parts of words. It can also help readers to understand the state of mind of the writer.

- Capitalization

Capitalization is practices of using capital letters in writing or printing.

- Spelling

Spelling is the process or activity of writing or naming the letters of a word. In other word, spelling is the writing of one or more words with letters.

5. Content
Content is how the writer develop his/her idea related with the topic that he or she wants to discuss.

Based on the theories above, the researcher emphasized this research to the last component, content. Mainly to find out whether the students are able to differentiate between the last paragraphs content between Hortatory and Analytical focuses on the existance of reiteration and recommendation.

\section{METHOD}

This research is considered as qualitative. It is a research procedure which produces descriptive data in the forms of written from the respondent. Qualitative research focuses on understanding social phenomena and providing rich verbal descriptions of settings, situations, and participants (Ary, Jacobs, \& Sorensen, 2010, p. 39). The research was conducted in Serang Raya University Jalan Raya Serang Cilegon Drangong Kelurahan Taktakan Serang Banten and the subject of this research is the of 2 nd Semester students of Sistem Komputer Class in Engineering Informatics Program University Of Serang Raya for 53 students.

The instrument used to collect the data in this research was writing test in the form of writing text and google form test. 
The Google form test was used to know how students able to differentiate reiteration and recommendation and writing test to know how they can write reiteration and recommendation. The researcher tried out the test to the students out of sample before giving the real test. It was done to let us know whether the students understood the instruction or not, and to see whether the time allocation was enough or not.

Then data collected and ready to analyze. There are two assessor will be analyze it. These following step are taken to analyze the data:

1. The researchers calculate the percentage of the students who can differentiate between reiteration and recommendation

2. The researchers interpret and analyze whether the students are able to write reiteration and recommendation by $\mathrm{him} /$ herself

\section{DISCUSSION}

This research aims to find out how many students can differentiate between reiteration and reccomendation and are they able to write reiteratin and recommendation.

The result how many students can differentiate between reiteration and recommendation. From 53 subjects, the data gained as follow:
1. The first question is: Hortatory Exposition is a text that...

There are 44 students answer correctly

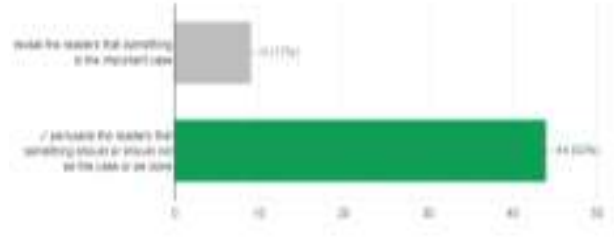

2. The second question: Analytical Exposition is a text that...

There are 38 students answer correctly

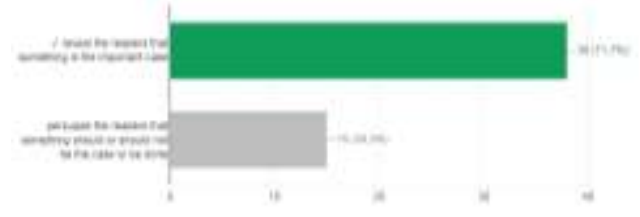

3. The third questions: Analytical Exposition...

There are 31 students answer correctly

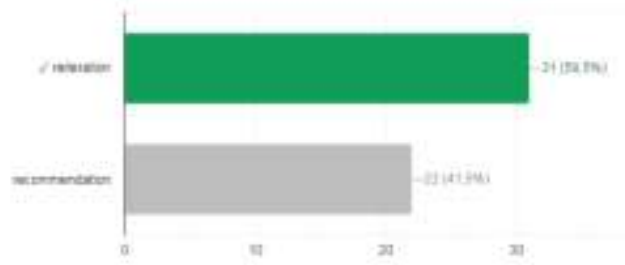

4. The fourth question: Hortatory exposition:

There are 33 students answer correctly

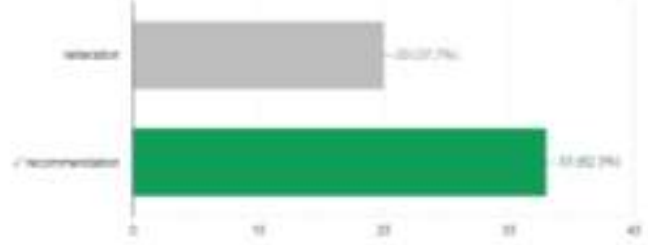

5. The fifth questions: "From the argument above we can conclude that smoking is dangerous for our health" There are 37 students answer correctly 


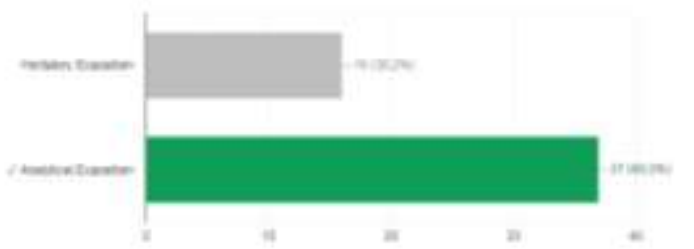

6. The sixth questions: "We ought not to waste time"

There are 34 students answer correctly

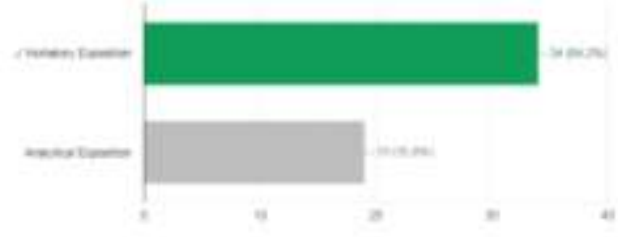

7. The seventh questions: "How is/will" There are 33 students answer correctly

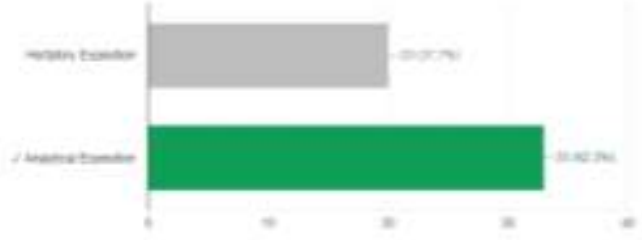

8. The eighth questions "How should".

There are 35 students answer correctly

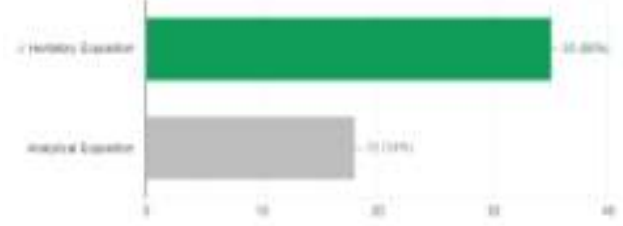

9. The ninth Question: "From the elaboration above, it`s fun learning English through songs"

There are 35 students answer correctly

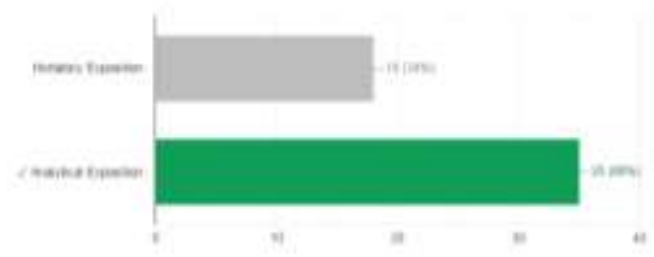

10. The tenth question: "From the elaboration above, it can be suggested that learning through music and songs, learning English can be enjoyable and fun"

There 29 students answer correctly

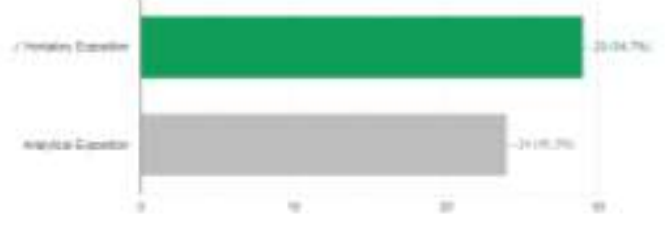

The result how many students are they able to write reiteration and recommendation where the indicator is the existence of reiteration and recommendation as follow:

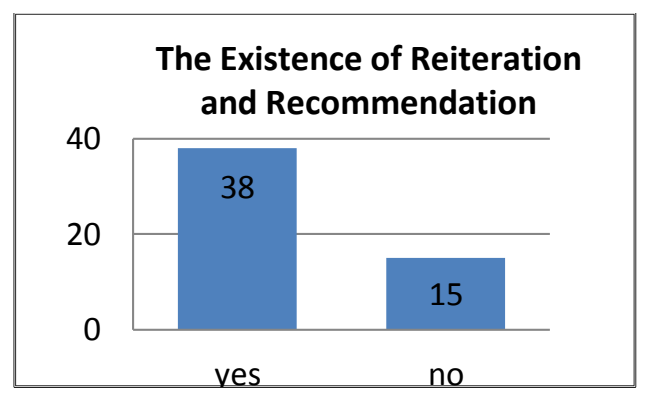

From the table above we can see that there are 38 students from 53 samples whom are able to write down the reiteration and recommendation from the text they made in the exam.

\section{CONCLUSION}

The result on how many students can differentiate between reiteration and recommendation can be seen at the diagram below: 


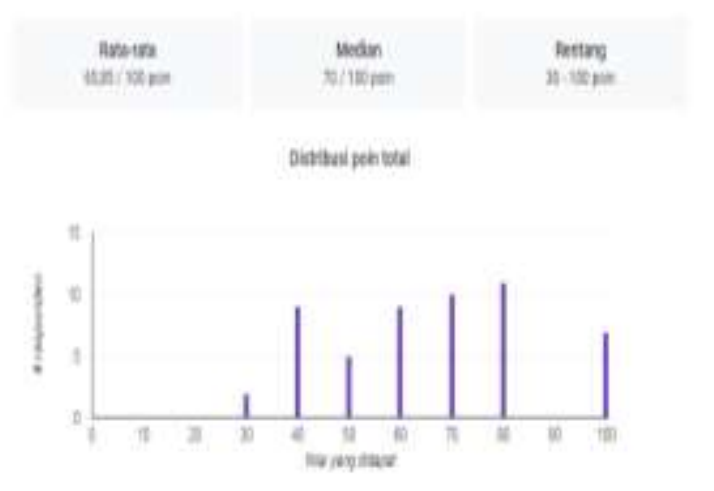

From the diagram above the average score is 65,85 . It means that the abilty to differentiate hortatory and explanation is in a fair condition. It means that there are still many students that are not able to differ both texts. The result on how many student are able to write reiteration and recommendation are shown as follow:

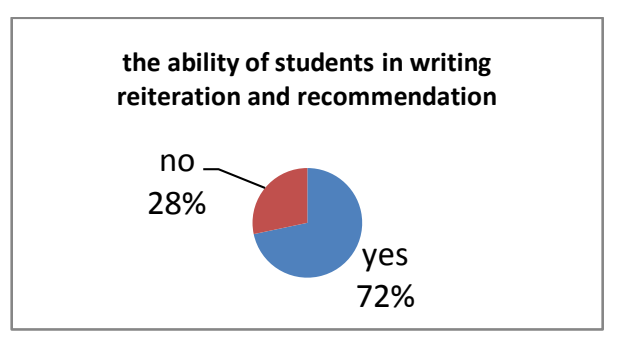

From the sample given, there are $72 \%$ of students are able to write reiteration and recommendation.

\section{REFERENCES}

Arikunto, Suharsimi. 2010. Dasar-dasar Evaluasi Pendidikan. Jakarta: Bumi Aksara

Bailey, Stephen. 2003. Academic Writing: A Practical Guide for Students. New York: RoutledgeFalmer.

Brown, H Douglas. 1994. Teaching by Principles: An Interactive Approach to Language
Pedagogy. New Jersey: Prentice Hall Regents.

Brown, $\mathrm{H}$ Douglas and Priyanvada Abeywickrama. 2010. Language Assessment: Principles and Classroom Practices (Second Edition). San Fransisco: Pearson Education.

Coulmas, Florian. 2003. Writing Systems: An Introduction to their Linguistic analysis. New York: Cambridge University Press.

Gay, L. R. 1987. Educational Research: Competencies for Analysis and aplication. Third Edition.New York: Merill Publishing Company.

Gerot, Linda and Peter Wignell.1994. Making Sense of Functional Grammar: An Introductory Workbook. Sydney: Gerd Stabler.

Gordon, Louise. 2008. "Writing and good language learners", in Griffiths, Carol (ed.), Lessons From Good Language Learner (p. 244-254). Cambridge: Cambridge University Press.

Halliday, M. A. K. and Ruqaiya Hasan. 1976. Cohesion in English. London: Longman Group Limited.

Hamp-Lyons, L. 1992. "Holistic writing assessment for LEP students",in Office of Bilingual Education and Minority Languages Affairs (ed.), Proceedings of the Second National Research Symposium on Limited English Proficient Student Issues: Focus on Evaluation and Measurement, Volume2. Washington, DC: OBEMLA. 317-358. 
Kehler, Andrew. 2002. Coherence, Reference, and the Theory Grammar California: CSLI Publications.

Knapp, P. and Megan Watskin. 2005.Genre, Text, Grammar: Technologies for Teaching Writing and Assessing Writing. Sydney: A UNSW Press Book.

Louwerse, M.M. and Graesser, A.C. 2005. Coherence in Discourse. In Strazny, P. (ed), Encyclopedia of Linguistics. Chicago: Fitzroy Dearborn.

Matthews, P.H. 2007. The Concise Oxford Dictionary of Linguistics. Oxford: Oxford University Press.

Murray, Rowena and Sarah Moore. 2006. The Handbook of Academic Writing: A Fresh Approach. Berkshire: Mc. Graw-Hill Open University Press.

O’Malley, J. Michael. and Lorraine Valdez Pierce. 1996. Authentic Assessment for English Language Learners: Practical Approaches for Teachers. Virginia: Addison-Wesley Publishing Company.

Oshima, Alice. and Ann Hogue. 1991. Writing Academic English. United Stated of America: Addison-Wesley Publishing Company, Inc.

Richards, Jack C. and W.A.Renandya. 2002. Methodology in Language Teaching: An Anthology of Current Practice. Cambridge: Cambridge University Press.

Swales, John M. and Christine B.
Tasks and Skills (Second Edition). Michigan: The University of Michigan Press.

Tanskanen, Sanna-Kaisa. 2006. Collaborating Towards Coherence: Lexical Cohesion in English Discourse. Amsterdam/Philadelphia: John Benjamins Publishing Company.

Ur, Penny. 1991. A Course in Language Teaching: Practice and Theory. Cambridge: Cambridge University Press.

Zemach, Dorothy E.. and Lisa, A.

Rumisek. 2005. Academic Writing: From Paragraph to Essay. Oxford: Macmillan Publisher Limited.

Zemach, Dorothy E.. and Lisa, A.

Rumisek. 2003. College Writing: From to Essay. Paragraph Oxford: Macmillan Limited. Publisher Industri, 15(2), 114-127.

Feak. 2004. Academic Writing for

Graduate Students: Essential 